\title{
Regulatory framework of small-scale fishers in Bangladesh: Safeguard or jeopardy?
}

\author{
Md. Mizanur Rahman \\ Deputy Secretary, Information and Communication Technology Division, Government of the \\ People's Republic of Bangladesh \\ E-mail: rahmanboku@gmail.com
}

\begin{abstract}
The chapter aims to analyze the legal and institutional framework for managing small-scale fisheries (SSF) in Bangladesh. It was found that the overarching institutional framework is embroidered with a paradoxical allocation of business, jurisdictional overlapping, conflict of interests, infirmed coordination and integration mechanism, and down and out fisheries governance. The legal framework is entangled with outworn, scattered, and segmented laws and widespread non-compliance. The existing legal and institutional framework is not well suited to establish SSF's rights to natural and financial resources. The market chain is controlled by many intermediary groups, which causes a deprivation in income and increases inequality. The hegemony of commercial fishers sidelines SSFs. The chapter recommends the re-allocation of business of the Ministry of Fisheries and Livestock. Active participation of the SSF in governance and resource management is warranted to minimize common's tragedy.
\end{abstract}

Keywords: Small-scale fishers, common's tragedy, deprivation, inherent rights, regulatory framework 


\section{A glimpse of SSF in Bangladesh}

The small-scale fishers usually live in coastal areas and catch fish using traditional knowledge, techniques, and equipment for their livelihood. Near about 17 million people are involved in this sector representing approximately the country's 11\% total population (Alam et al., 2021). Furthermore, SDG 14 emphasized the importance of SSF. SDGs advocate for SSF's access to resources and markets. Bangladesh also accepted the aspiration of a "leaving no one behind" approach to meet SDGs. Hence, this chapter focused on analyzing the drawbacks of the legal and institutional framework embedded in SSF. An ordinance and few rules provide a legal framework for SSF, but they are very old and are not appropriately enforced for multiple reasons. On the other hand, the institutional mechanism is not well developed to engage multistakeholders and develop coordination among different actors (Islam, 2012; Shamsuzzaman and Islam, 2018). There are ambiguities in the allocation of business and the parental ministry and departments' role and responsibility. The sustainable outreach use of marine fishes is capped by several factors like lack of knowledge on the potential resources, inadequate mapping of the resources, and erroneous institutional and legal frameworks (Shamsuzzaman et al., 2017a, b). The reformation of the legal and institutional framework can facilitate SSF's right to natural resources. The reform is indispensable for enhancing small-scale fisheries and sustainable extraction of marine living resources. Hence, this chapter contributed to coming up with solutions to improve SSF's rights to resources.

\section{Rebuffed legal protection}

The marine and coastal resources in Bangladesh are regulated by a few old marines and inland laws (Rahman, 2021). The "Marine Fisheries Ordinance, 1983" stressed establishing marine reserves. The "Protection and Conservation of Fish Rules, 1985" were framed to fulfill that ordinance's overall objectives. The rules have also emphasized conservation. The "Bangladesh Merchant Shipping Ordinance, 1983" sketched the registration procedures of marine vessels. "Bangladesh Oceanographic Research Institute Act, 2015" was enacted to carry out research on oceanography. The "Environment Conservation Act, 1995" was depicted to preserve biodiversity through ecosystem management and controlling pollution. In this act, there is a provision of declaring "ecologically critical areas (ECAs)." The "Department of Environment" was established and legitimized by this act. The "Bangladesh Environment Conservation (Amendment) Act, 2010' made clarity in the definition of ecosystem, ecologically critical area, and wetland. "The Ecologically Critical Area Management Rules, 2016" were approved consequently. These rules formed various committees starting from national to grass root levels incorporating diverse stakeholders. The "Bangladesh Environment Court Act, 2010" was enacted to ensure justice against any sorts of environmental and social damage. The "Bangladesh Biodiversity Act, 2017" focused on achieving three goals of "The Convention on Biological Diversity (CBD)." The "Wildlife (Conservation and Security) Act, 2012" explained different terminology related to forest biodiversity, especially wildlife and conservation. The Forest Department is entitled to conserve and manage the biodiversity of the country. The "Weather Act (Abhawa Ain), 2018" entrusted "Bangladesh Meteorological Department to prepare a strategic action plan incorporating the guidelines of the "Intergovernmental Oceanographic Commission (IOC)" and the "International Maritime Organization (IMO)." The "Coast Guard Act, 2016" was ratified to define the functions, jurisdictions, and code of conducts of the "Bangladesh Coast Guard." The "Disaster Management Act, 2012" legitimized the organizational structure of 
disaster management. From the above discussion, it is clear that no existing law was enacted to provide a guideline for the SSF and acknowledge their rights to resources.

\section{Webby institutional arrangements}

The institutional framework for regulating small-scale fisheries is characterized by a complex arrangement involving a mix of formal and informal institutions like public departments, nongovernment organizations, private sectors, and communities (Shamsuzzaman and Islam, 2018). "Ministry of Fisheries and Livestock" should be considered the nodal public institution, which paid scarce attention to SSF in its business allocation. Contradictorily, a single word indicating marine fishery is not found in the business allocation of "Ministry of Environment, Forest and Climate Change" (Rahman, 2021a). However, it plays a crucial role in regulating fisheries in the mangroves' wetlands, coastal forest areas, and the "Swatch of no Ground." Consequently, the fishermen community in the Sundarbans mangrove areas hangs around a double-edged sword. Per the mandates defined by the laws, the "Department of Environment" maintains water quality in the fishing grounds. Forest Department works on behalf of the sister "Department of Environment," which has not premises and staffs at the grassroots level (Rahman, 2021). Consequently, it can be argued that foresters are the key actors in regulating SSF in Bangladesh. The "Bangladesh Fisheries Research Institute (BFRI)" conducts research on both freshwater and marine fisheries, but it not incapable enough to carry out need-based research for SSF. The newly established "Oceanographic Research Institute" has started walking and limping with underdeveloped legs.

\section{The conflict between security measures and insecurity}

Security and law enforcement is one of the grey areas and crucial challenges for SSFs in Bangladesh. Piracy is considered the life-threatening concern of SSF. Often the local pirates kidnap and kill them. The foreign pirates attack suddenly to loot fish and other valuable items. They slaughter the fishers by using sharp knives. Many law-enforcing agencies like River Police, Bangladesh Coast Guard, Rapid Action Battalion, Forest Guard, and Bangladesh Navy work to ensure security. Different studies showed that due to a lack of coordination and a proactive approach, the pirates remain untouched in many cases (Alam et al., 2021). Simultaneously, the SSFs cannot determine the focal point or coordinating agency, which is primarily responsible for controlling piracy.

\section{The hegemony of the intermediaries in the market chain}

The formal banking channel is not interested in providing the loan to SSFs. Therefore, SSFs depend on Dadan (local credit) and Mahajan (local moneylenders). The SSF has to pay between $80 \%$ to $120 \%$ interest to Mahajan under this Dadan system (Rahman and Alam 2020, Rahman et al., 2021). There are seven classes of intermediaries in the fish market: collector, majhi (the Captain of the boat), Chhoto Mahajan (small moneylender), Boro Mahajan (big moneylender), Aratdars (stocker and preserver), wholesaler, and retailer. SSF receives only $30 \%$ of retail prices (Alam et al., 2021). In the Dadan system, the fishers are obliged to sell fish to the Mahajan who provided the loan.

\section{Common's tragedy}


Ordinary people cannot seek environmental justice directly in Bangladesh (Rahman 2021b). Consequently, SSFs are deprived of various inherent rights. The commercial fishers occupy SSF's fishing grounds due to weak monitoring, control, and surveillance system. It is reported that the fish stock near the shore is declining sharply due to incremental incursion of the commercial fishers. Likewise, most SSFs live on government-owned land, locally known as 'khas land.' In remote areas, they are deprived of medical facilities, electricity, life support equipment, and communication devices in many cases. The dadan system, market intermediaries, and commercial fishers spawn SSF's tragedy. Nobel laureate Elinor Ostrom termed these deprivations as the "Tragedy of the Commons" (Ostrom, 1990).

\section{What to do?}

Fisheries laws should be updated by merging scattered and fragmented laws. Before the amendment of the existing laws or enacting new laws, the current laws' enforcement should be ensured. Everybody's business turns into nobody's business, and many players can make a game messy. The allocation of business of the "Ministry of Fisheries and Livestock" should be revised to include its prominent role in regulating SSFs. On the other hand, the foresters' role should be confined to terrestrial ecosystems. The business re-allocation can facilitate establishing fisheries governance. Ministry of Fisheries and Livestock can develop spatial and temporal governance with the Bangladesh Navy and Bangladesh Coast Guard's help.

Monitoring, control, and surveillance systems should be activated and modernized to control commercial fishers' hegemony over SSFs. SDG target 2.b. stresses on correcting the market chain and clearing all obstacles to ensure food security. Department of Fisheries should work closely with the Trading Corporation of Bangladesh (TCB) to clear the fish market chain intermediaries. The marketing system and fish landing stations should be modernized. The active participation of SSFs in coastal governance should be legitimized to develop polycentric governance. The state banks should provide loans to stop the monopoly business of the local lenders (Mahajan). The Department of Fisheries should be equipped with the necessary logistics and workforce at the operational level. Otherwise, common's tragedy will be heightened, increasing inequalities.

\section{References}

Alam, S., Rahman, M.M. and Arif, A.A. (2021). Challenges and opportunities in artisanal fisheries (Sonadia Island, Bangladesh): The role of legislative, policy and institutional frameworks. Ocean \& Coastal Management, 201, 105424, https://doi.org/10.1016/j.ocecoaman.2020.105424.

Islam, M.M. (2012). Poverty in small-scale fishing communities in Bangladesh: context and responses. PhD Thesis, University of Bremen, Germany.

Ostrom, E. (1990) "Governing the Commons: The Evolution of Institutions for Collective Action”, Cambridge, UK: Cambridge University Press.

Rahman, M.M. (2021). The rhetorical blue economy in Bangladesh: Analyzing the inborn regulatory bottlenecks, Acta Aquatica: Aquatic Sciences Journal, 8 (2): 66-73. 
Rahman, M.M. (2021a), Achieving Sustainable Development Goals of Agenda 2030 in Bangladesh: the crossroad of the governance and performance, Public Administration and Policy: An Asia-Pacific Journal, 24 (2): 195-211. https://doi.org/10.1108/PAP-12-2020-0056

Rahman, M.M. (2021b) Biologia Futura: can co-management protect Saint Martin's corals of Bangladesh? BIOLOGIA FUTURA (2021). https://doi.org/10.1007/s42977-021-00101-4

Rahman, M.M., Alam, M.A., Rahman, M.M., Mamun, M. and Alam, A. (2020). Challenges of Artisanal Fishermen: A Case Study from Sonadia Island, Bangladesh. In Alam, M.A., Alam, F. and Begum, D. (Eds.), Knowledge Management, Governance and Sustainable Development: Lessons and Insights from Developing Countries. India: Routledge. https://dx.doi.org/10.2139/ssrn.3773504.

Rahman, M.M., and Alam, M.A. (2020). Regulatory and Institutional framework for the conservation of coral reefs in Bangladesh: A Critical Review. In Alam, M.A., Alam, F. and Begum, D. (Eds.), Knowledge Management, Governance and Sustainable Development: Lessons and Insights from Developing Countries. India: Routledge, https://dx.doi.org/10.2139/ssrn.3794550.

Shamsuzzaman, M.M and Islam, M.M. (2018). Analysing the legal framework of marine living resources management in Bangladesh: Towards achieving Sustainable Development Goal 14. Marine Policy, 87: 255-262.

Shamsuzzaman, M.M, Xiangmin, X, Islam, M.M, Alam, M.W and Karim, E. (2017b). Sustainable Marine Fisheries Resources of Bangladesh: A Strategic Response for Economic Security. Indian Journal of Geo Marine Sciences, 46 (4): 757-765.

Shamsuzzaman, M.M., Islam, M.M., Tania, N.J., Al-Mamun, M.A., Barman, P.P. and Xu, X. (2017a). Fisheries resources of Bangladesh: Present status and future direction. Aquaculture and Fisheries, 2: 145-156. 